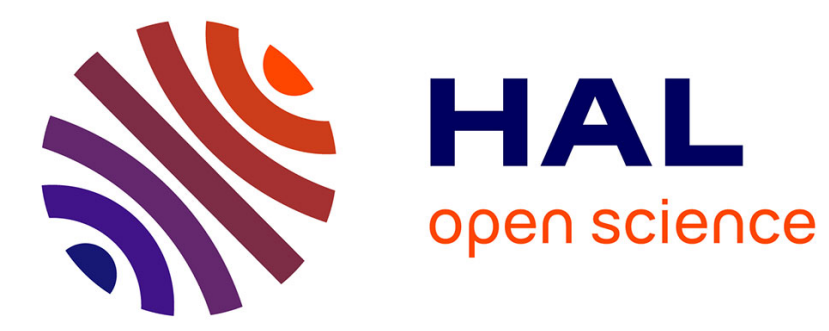

\title{
Pine heartwood and glass surfaces: easy method to test the fate of bacterial contamination
}

Tiina Vainio-Kaila, Aino Kyyhkynen, Pertti Viitaniemi, Anja Siitonen

\section{To cite this version:}

Tiina Vainio-Kaila, Aino Kyyhkynen, Pertti Viitaniemi, Anja Siitonen. Pine heartwood and glass surfaces: easy method to test the fate of bacterial contamination. European Journal of Wood and Wood Products, 2010, 69 (3), pp.391-395. 10.1007/s00107-010-0453-7 . hal-00615327

\section{HAL Id: hal-00615327 \\ https://hal.science/hal-00615327}

Submitted on 19 Aug 2011

HAL is a multi-disciplinary open access archive for the deposit and dissemination of scientific research documents, whether they are published or not. The documents may come from teaching and research institutions in France or abroad, or from public or private research centers.
L'archive ouverte pluridisciplinaire HAL, est destinée au dépôt et à la diffusion de documents scientifiques de niveau recherche, publiés ou non, émanant des établissements d'enseignement et de recherche français ou étrangers, des laboratoires publics ou privés. 
Ejwwp453_source

\title{
Pine heartwood and glass surfaces: easy method to test the fate of bacterial contamination
}

\author{
Tiina Vainio-Kaila ${ }^{1,2}$, Aino Kyyhkynen ${ }^{2}$, Pertti Viitaniemi ${ }^{1}$ and Anja Siitonen ${ }^{2}$ \\ ${ }^{1}$ Helsinki University of Technology, Faculty of Chemistry and Materials Sciences, \\ Department of Forest Products Technology. PL 6400, 02015 TKK, Finland \\ Tiina.vainio-kaila@tkk.fi \\ ${ }^{2}$ Gastrointestinal Infections Unit, Department of Infectious Disease Surveillance \\ and Control, National Institute for Health and Welfare, Helsinki, Finland
}

\section{Abstract}

The survival of two bacteria, Escherichia coli and Listeria monocytogenes was observed on pine heartwood and glass surfaces by using a simple test method. The development of the number of bacterial cells was evaluated by titration after vortexing the samples in BHI broth and culturing the resulting broth on agar plates. The bacterial count decreased clearly faster on pine heartwood than on glass surfaces. This result was confirmed by studying the wooden samples also one day after to exclude possible adherence of the bacterial cells on the porous surface. This study confirms the results of several other studies that suggest wood to have antibacterial properties.

Kiefernkernholz und Glasoberflächen: eine einfache Methode zur Prüfung von Bakterienbefall

\section{Zusammenfassung}

Das Überleben von zwei Bakterienarten, Escherichia coli und Listeria monocytogenes, auf Kiefernkernholz und Glasoberflächen wurde mit einer 
Ejwwp453_source

einfachen Prüfmethode untersucht. Mittels Titrierung wurde die Entwicklung der Anzahl der Bakterienzellen untersucht, nachdem die Proben in einer BHI-

Nährlösung gevortext wurden, die anschließend auf Agarplatten kultiviert wurde.

Die Keimzahl nahm auf Kiefernkernholz deutlich schneller ab als auf Glasoberflächen.

Dieses Ergebnis konnte auch durch Untersuchungen der Holzproben am darauf folgenden Tag bestätigt werden, um ein mögliches Anhaften der Bakterienzellen auf der porösen Oberfläche auszuschließen. Mit dieser Studie konnten die Ergebnisse früherer Untersuchungen bestätigt werden, die Holz antibakterielle Eigenschaften zuschreiben.

\section{Introduction}

Whether wood surfaces are hygienic or not has been widely discussed especially in regard to cutting boards. Several researchers have found wood more difficult to clean than plastic boards and therefore a more hygienically unfavorable material (Gilbert and Watson 1971; Abrishami et al. 1994; Gough and Dodd 1998). On the other hand, there are several studies suggesting that wood has antibacterial properties against Listeria monocytogenes, Salmonella serotype Typhimurium (Ak et. al. 1994 a, b), Enterococcus faecium (Milling 2005a), enterobacteria, enterococci and streptococci (bacteria from chicken manure) (Milling 2005b), Bacillus subtilis and Pseudomonas fluorescens (Koch et. al. 2002). The reasons behind antibacteriality are not well understood; it is supposed to be a combination of several factors such as wood surfaces drying and chemical composition (Schönwälder et al. 2002). Some of the chemical components have been studied separately. Lindberg et al. (2004) have found the concentration of pinosylvin to correlate with antibacteriality against $B$. coagulans, Burkholderia multivorans and Alcaligenes xylosoxydans. Mourey and Canillac (2002) have found $\alpha$-pinene to inhibit the growth of L. monocytogenes. Also the resin of Norway spruce (Picea abies) has been found to have antibacterial effect on several Gram-positive bacteria (Sipponen et. al. 2007).

The purpose of this study was to investigate the antibacterial effect of wood by comparing wooden and glass surfaces using a simple test method. Preferably, a 
Ejwwp453_source

method was wanted, which could be standardized and which was easy to repeat. To be able to study wooden surfaces it was chosen to use solid wood pieces instead of sawdust. Escherichia coli and L. monocytogenes were used as hygienically relevant Gram-positive and Gram-negative test bacteria, respectively. Both bacterial species are also common human pathogens.

\section{Materials and methods}

\section{Wood and glass cylinders}

The wood material used in these tests was heartwood of Scots pine (Pinus sylvestris). The test samples were cut within six months from sawing and used within one week from manufacturing the test samples. The samples were made by drilling cylinders with a diameter of $15 \mathrm{~mm}$ and a surface area of circa 176.7 $\mathrm{mm}^{2}$. The thickness was $10 \mathrm{~mm}$. Glass cylinders of same diameter and surface area were ordered from a company making laboratory equipment. The thickness of glass samples was $3 \mathrm{~mm}$.

\section{Bacterial strains}

L. monocytogenes $1 / 2 \mathrm{a}$ (IH 83616 [isolated from the blood sample of a patient]) and E. coli (MG 1655; Guyer et al. 1981) were stored in skimmed milk at $-70^{\circ} \mathrm{C}$. Prior to use, L. monocytogenes and E. coli were subcultured at least twice on sheep blood and Drigalski-Conradi agar plates, respectively. The plates were incubated at $37^{\circ} \mathrm{C}$ overnight. Bacterial colonies were moved directly from agar to physiological $\mathrm{NaCl}$ solution, and the concentration was adjusted to $1.5 \times 10^{8}$ CFU/ml using a photometer (Gene-Trak Systems,Hopkinton, MA, USA). This was equivalent to photometer reading 0.13 corresponding to McFarland 0.5. Serial dilutions of the bacterial suspensions were then prepared in physiological $\mathrm{NaCl}$ to correspond to the concentrations of $1.5 \times 10^{6}, 1.5 \times 10^{4}$ and $1.5 \times 10^{2} \mathrm{CFU} / \mathrm{ml}$. These and the original concentrations were used in preliminary tests to find the most suitable one for the experiments. The concentration $1.5 \times 10^{6} \mathrm{CFU} / \mathrm{ml}$ was chosen for final tests. 
Ejwwp453_source

\section{Cultivations}

$100 \mu \mathrm{l}$ of bacterial solution was placed on wooden and glass samples which is equivalent to $1.5 \times 10^{5} \mathrm{CFU}$ per sample. Five parallel samples were used for each of the five incubation times. The samples were placed in large petri dishes, the five parallel samples in each of them. 25 wood as well as 25 glass samples were inoculated with both L. monocytogenes and E. coli, 100 samples altogether. After incubation at $25{ }^{\circ} \mathrm{C}$ for $1 \mathrm{~h}, 2 \mathrm{~h}, 4 \mathrm{~h}$, about $1 \mathrm{~d}(22 \mathrm{~h}$ for $L$. monocytogenes and $28 \mathrm{~h}$ for E. coli) and about $2 \mathrm{~d}$ ( $44 \mathrm{~h}$ for L. monocytogenes and $52 \mathrm{~h}$ for $E$. coli), the samples were tested for recoverable bacteria. To remove all adhered bacterial cells from the surface of the samples, they were vortexed in $15 \mathrm{ml} \mathrm{BHI}$ (brain heart infusion) broth for $5 \mathrm{sec}$. Immediately afterwards, $400 \mu \mathrm{l}$ of the broth with $L$. monocytogenes or E. coli was spread onto sheep blood or Drigalski-Conradi agar plates, respectively. After overnight incubation at $37{ }^{\circ} \mathrm{C}$, the CFUs on the plates were counted. In cases where the bacterial colonies formed a lawn on the plates and, thus were impossible to count separately, the CFUs were estimated to correspond to the original number of cells at $0 \mathrm{~h}$ (i.e., $1.5 \times 10^{5}$ ). The average and the standard deviation of the five parallel results were calculated, and the results are shown as CFU/plate in a logarithmic scale.

Because wood is accused of collecting bacteria tightly adhered to its porous surface, the wood samples were further tested. The BHI broth tubes with wood samples in BHI broth were also studied after incubation overnight at $37^{\circ} \mathrm{C}$ where the bacterial cells were expected to multiply even if they were tightly adhered to the surfaces. The next day, $400 \mu 1$ of the broth containing samples with $L$. monocytogenes, was spread again onto sheep blood agar and incubated at $37{ }^{\circ} \mathrm{C}$ overnight. Only the samples of 2, 4 and 22 hours were tested this way in order to see the potential difference of the results compared with those after vortexing. Also the test tubes with $E$. coli were incubated at $37^{\circ} \mathrm{C}$ overnight, and the bacterial growth was investigated directly by looking for turbidity or clarity of the broth. The results are shown as + or - for growth or no growth, respectively.

\section{Results}

To define optimal bacterial concentration and incubation times for the final method, preliminary examinations were carried out. Based on these results (data 
Ejwwp453_source

not shown), the concentration $1.5 \times 10^{6} \mathrm{CFU} / \mathrm{ml}$ corresponding to $1.5 \times 10^{5}$ CFU/sample was chosen. At this concentration, the CFUs of both $L$. monocytogenes and E. coli started decreasing after two hours of incubation on wood samples.

It was clearly shown that bacterial numbers of both strains decreased more quickly on wooden surfaces compared to the glass surfaces. (Fig. 1 and 2). The difference between the reductions is considerable for the $2 \mathrm{~h}$ and $4 \mathrm{~h}$ incubation at $25{ }^{\circ} \mathrm{C}$ for both bacterial strains. For L. monocytogenes the difference is considerable also for $22 \mathrm{~h}$ and $44 \mathrm{~h}$ incubation times. Already after 2 hours of incubation a reduction of viable counts of bacterial cells could be seen on wooden surfaces with both test bacterial strains. On average, there were $300 \mathrm{CFUs} /$ plate of L. monocytogenes and $350 \mathrm{CFUs} /$ plate of E. coli meaning $0.2 \%$ of the original $1.5 \times 10^{5} \mathrm{CFU} /$ sample. After 4 hours there was a $\log 2$ reduction on wooden surfaces and no change in the count of bacterial cells on glass surfaces for both bacterial strains. The number of $L$. monocytogenes was on average $12 \mathrm{CFUs} /$ plate and the number of E. coli was on average $19 \mathrm{CFUs} /$ plate. The results from the parallel wood samples varied more than the results from the parallel glass samples (Fig. 1 and 2).

On glass samples, the reduction of both bacteria was only seen after about one day of incubation at $25^{\circ} \mathrm{C}$ (Fig. 1 and 2). The number of L. monocytogenes on glass surfaces (on average $23 \mathrm{CFU} /$ plate) was greater than for $E$. coli (on average less than one CFU/plate) and neither could be found on wooden surfaces. $L$. monocytogenes survived longer on glass surfaces than E. coli.

To study the possibility of bacteria tightly adhering to the wood surfaces, the BHI test tubes with samples were further tested after overnight incubation at $37^{\circ} \mathrm{C}$. There was one of the 15 tested wood samples with $L$. monocytogenes that showed growth even though in the original test after 22 hours at $25^{\circ} \mathrm{C}$ there had been no bacterial growth. None of the other tested wood samples with L. monocytogenes showed growth on the following day unless there had been growth the first day 
Ejwwp453_source

(Table 1). Subculturing after overnight incubation at $37{ }^{\circ} \mathrm{C}$ was not necessary for the BHI tubes E. coli: if there was no bacterial growth, the BHI broth was clear and if there was bacterial growth, the broth was turbid. None of the tested wooden specimens with $E$. coli showed growth on the following day unless there had been growth the first day. (Table 1)

\section{Discussion}

The survival of L. monocytogenes and E. coli was studied on wooden and glass surfaces, and bacterial counts on each surface were compared. The number of bacterial cells used was $1.5 \times 10^{5}$ CFU per sample. This number was high enough to show reliably the reduction of the bacteria on both surfaces. However, it was not too high to demand several sets of serial dilutions to see this reduction. In addition, to increase the reliability of the study design, five parallel samples were monitored for each experiment. Also, five different incubation times were used. Throughout the tests, the difference between wood and glass surfaces could be seen only after $2 \mathrm{~h}$ incubation at $25{ }^{\circ} \mathrm{C}$. The normal variation of room temperature was avoided by using the incubator with controlled temperature. In these controlled conditions, the bacterial count clearly declined faster on wooden surfaces compared to glass surfaces.

There is a wide range of studies comparing wooden and plastic cutting boards. This study has brought the hygienic properties of wood on a more general level. The comparison was made between wood and glass. Glass is considered a neutral material, which should not affect the bacterial growth in any way. This gave the opportunity to study the antibacterial effect of wood by comparing it with a material without any effect. The most common methods used in similar studies are a contact plate method (Ak. et al. 1994 a, b; Park and Cliver 1996; Gough and Dodd 1998; Schönwälder et al. 2002; Koch et al. 2002; Milling et al. 2005b; Boursillon and Riethmüller 2007) where agar medium is pressed directly onto the test surface and a swab method (Gilbert and Watson 1971; Park and Cliver 1996; Miller et al. 1996; Welker et al. 1996; Koch et al. 2002) where the test surface is swept with a swab or a sponge, and the bacterial count from the swab is then studied. Vortexing was chosen in the current study to avoid the possible effect of adherence. Destructive methods have been used by Park and Cliver (1996) and 
Ejwwp453_source

Schönwälder et al. (2002). This allows using solid wood samples and excludes the effect of adherence. However, it is faster and easier to use small enough samples to be tested entirely, as was done in this study. Abrishami et al. (1994) used $8.9 \times 8.9 \mathrm{~cm}^{2}$ wood samples which were placed into a cylindrical jar in buffer liquid and shaken for 2-3 minutes, but the authors did not explain how the shaking was done in the cylindrical jar. Schmidt (1989) also used a similar method rinsing the solid wood samples in succession in a plastic bag with $50 \mathrm{ml}$ physiological salt solution. However, vigorous vortexing is presumably more effective than rinsing.

L. monocytogenes presents hygienically relevant Gram-positive bacterial species that often causes contaminations, for example in fish production factories (Miettinen et. al. 2001). E. coli was chosen as a Gram-negative reference bacterium to indicate potential faecal contamination. First of all, the study aimed at developing a simple test method that could be used in future studies to reveal the reasons behind the antibacterial properties of wood. Pine was chosen because of its known antibacterial properties (Milling et. al. $2005 \mathrm{a}, \mathrm{b}$ ), and since it is one of the most common wood species sawn in Finland. To study wooden surfaces, solid blocks were used instead of sawdust (Milling et. al. 2005 a,b).

Wood has been accused of adherence of bacteria tightly on the surface because of its porous structure (Abrishami et al.1994; Gough and Dodd,1998). To study other possible effects on the antibacterial properties, adherence to the surface had to be eliminated. For this reason, the samples were placed in the test tubes with BHI broth and shaken thoroughly with Vortex instead of using the contact method (Ak et. al. 1994 a, b; Gough and Dodd 1998; Schönwälder et. al. 2002). The samples were also left overnight in BHI broth and investigated the next day to find out if there had been viable adhered bacteria on those samples where the first cultivation produced no bacteria. This showed very good correlation. Namely, if the cultivation directly from $\mathrm{BHI}$ broth had given $0 \mathrm{CFU}$ as a result, there was no growth later either. Instead, if there had been any CFUs in previous cultivation, the next day's results also showed bacterial growth. This clearly shows that the porous structure of wood does not account for the faster decrease of bacterial count on wood compared to glass. 
Ejwwp453_source

The method developed in this study is easy to use and the results clearly showed differences in the survival of bacteria on wooden and glass surfaces. Thus, this method will be very helpful when studying the nature of the antibacterial properties of wood. Five parallel samples, as used in this study, showed reliably the different effect of the two matrices, wood and glass, on the reduction of the bacterial counts of two hygienically important bacterial species, L. monocytogenes and E. coli. However, wood as a natural material is very heterogeneous and to get robust results several parallel tests are necessary. Pine heartwood was chosen for this study, and these results can not be generalized for all the wood species. Each species needs to be tested separately, and for some species there can even be differences between heartwood and sapwood, since their chemical composition might differ from each other (Bertaud and Holmbom, 2004).

The antibacterial properties of wood might bring some new viewpoints regarding the use of wood as an interior material. These properties have already been exploited in e.g. wooden pens, bed mats, bath mats and different skin treatment products (www.wilms.com). Natural anti-microbial properties offer an interesting possibility for product development.

It would also be important to study the hygienic properties of wood because it has a reputation of being difficult to clean and unhygienic. This might lead to unfavorable choice of material e.g. when designing public buildings. For this purpose, more research on the effect of different surface coatings is necessary. The material used in this study was new; the wood was only half a year old. Normally, the surface materials, like wall panels, are in use for years. Thus it would be important to research the effect of the age of wood.

Wood's activity against bacteria leads the researcher to other similar questions. How does wood affect impurities in indoor air or our own bodies? How do fungi producing toxins grow on wooden surfaces compared with competing materials? In addition, the question of what causes this interesting antibacterial effect needs to be answered in more research. 
Ejwwp453_source

\section{Conclusion}

The aim of this study was to compare the hygienic properties of wood and glass using a test method which is easy to repeat. The results clearly showed bacterial count to decrease faster on wood than glass surfaces. By using a method where the samples are vigorously vortexed, the adherence of the bacterial cells on the wood surface is shown to be an inadequate explanation for these results. Clearly, pine heartwood has antibacterial effects but to better understand the reasons behind it more research needs to be done.

\section{References}

Abrishami SH, Tall BD, Bruursema TJ, Epstein PS, Shah DB (1994) Bacterial adherence and viability on cutting board surfaces, Journal of Food Safety, vol. 14, no. 2, pp. 153-172.

Ak NO, Cliver DO, Kaspari CW (1994b) Decontamination of Plastic and Wooden Cutting Boards for Kitchen Use, Journal of food protection, vol. 57, no. 1, pp. 23-30.

Ak,NO, Cliver DO, Kaspari CW (1994a) Cutting Boards of Plastic and Wood Contaminated Experimentally with Bacteria, Journal of food protection, vol. 57, no. 1, pp. 16-22.

Bertaud F, Holmbom B (2004) Chemical composition of earlywood and latewood in Norway spruce heartwood, sapwood and transition zone wood, Wood Sci Technol, vol. 38, no. 4, pp. 245256.

Boursillon D, Riethmüller V (2007) The safety of wooden cutting boards: Remobilization of bacteria from pine, beech, and polyethylene, British Food Journal, vol. 109, no.4, pp.315-322.

Gilbert RJ, Watson HM (1971) Some laboratory experiments on various meat preparation surfaces with regard to surface contamination and cleaning, International Journal of Food Science \& Technology, vol. 6, no. 2, pp. 163-170.

Gough NL, Dodd CER (1998) The survival and disinfection of Salmonella typhimurium on chopping board surfaces of wood and plastic, Food Control, vol. 9, no. 6, pp. 363-368.

Guyer MS, Reed RR, Steitz JA, Low KB (1981) Identification of a sex-factor-affinity site in E. coli as gamma delta, Cold Spring Harbor symposia on quantitative biology, vol. 45 Pt 1, pp. 135140 .

Koch AP, Kofod CJ, Konova D, Kvist KE, Lindegaard B (2002) Wood, plastic and steel-a comparison of hygienic properties, Partial report, vol. 10, pp. 1-42.

Lindberg LE, Willför SM, Holmbom BR (2004) Antibacterial effects of knotwood extractives on paper mill bacteria, Journal of Industrial Microbiology and Biotechnology, vol. 31, no. 3, pp. 137147.

Miettinen H, Aarnisalo K, Salo S, Sjöberg A-M (2001) Evaluation of surface contamination and the precense of Listeria monocytogenes in fish processing factories, Journal of Food Protection, vol. 64 , no. 5 , pp. 635-639. 


\section{Ejwwp453_source}

Miller A, Brown T, Call JE (1996) Comparison of Wooden and Polyethylene Cutting Boards: Potential for the Attachment and Removal of Bacteria from Ground Beef, Journal of Food Protection, vol. 59, no.8, pp. 854-858.

Milling, A, Kehr R, Wulf A, Smalla K (2005a) Survival of bacteria on wood and plastic particles: dependence on wood species and environmental conditions., Holzforschung, vol. 59, no. 1, pp. $72-$ 81.

Milling A, Smalla K, Kehr R, Wulf A (2005b) The use of wood in practice-a hygienic risk?, Holz Roh- Werkst, vol. 63, no. 6, pp. 463-472.

Mourey A, Canillac N (2002) Anti-Listeria monocytogenes activity of essential oils components of conifers, Food Control, vol. 13, no. 4-5, pp. 289-292.

Park PK, Cliver DO (1996) Disinfection of Household Cutting Boards with a Microwave Oven, Journal of food protection, vol. 59, no. 10, pp. 1049-1054.

Schmidt U (1989) Cleaning and disinfection methods - Effect of rinsing on surface bacterial count, Fleischwirtsch, vol. 69, no. 1.pp. 71-74.

Schönwälder A, Kehr R, Wulf A, Smalla K (2002) Wooden boards affecting the survival of bacteria?, Holz Roh- Werkst vol. 60, no. 4, pp. 249-257.

Sipponen A, Rautio M, Jokinen JJ, Laakso T, Saranpaa P, Lohi J (2007) Resin-Salve from Norway Spruce-A Potential Method to Treat Infected Chronic Skin Ulcers?, Drug Metabolism Letters, vol. 1, no. 2, pp. 143-145.

Welker C, Faiola N, Davis S, Maffatore I, Batt C (1996) Bacterial Retention and Cleanability of Plastic and Wood Cutting Boards with Commercial Food Service Maintenance Practices Journal of Food Protection, vol. 60, no. 4, pp. 407-413. 
Ejwwp453_source

Figure 1. Amount of CFUs of L. monocytogenes recovered from the wooden and glass surfaces after six different incubation times. The average of five parallel samples is shown and the error bars show the standard deviation.

Figure 2. Amount of CFUs of E. coli recovered from the wooden and glass surfaces after six different incubation times. The average of five parallel samples is shown and the error bars show the standard deviation.

Table 1. Occurrence of the bacterial growth of L. monocytogenes and E. coli on wooden surfaces in the two cultivations. The first +or- in slash shows whether there was any bacterial growth in the test after vortexing and the second +or- in slash shows whether there was bacterial growth one day later in the $\mathrm{BHI}$ broth incubated at $+37 \mathrm{C}$ overnight.

\begin{tabular}{|l|c|c|c|c|c|c|}
\hline \multirow{2}{*}{ Bacterial strain } & Incubation & \multicolumn{5}{|c|}{ Parallel samples } \\
\cline { 3 - 7 } & time & 1 & 2 & 3 & 4 & 5 \\
\hline L.monocytogenes & $2 \mathrm{~h}$ & $+/+$ & $+/+$ & $+/+$ & $+/+$ & $+/+$ \\
\hline L.monocytogenes & $4 \mathrm{~h}$ & $-/-$ & $+/+$ & $+/+$ & $+/+$ & $\mathrm{n} / \mathrm{a}^{\mathrm{a}}$ \\
\hline L.monocytogenes & $22 \mathrm{~h}$ & $-/-$ & $-/-$ & $-/-$ & $-/+$ & $-/-$ \\
\hline E.coli & $2 \mathrm{~h}$ & $+/+$ & $-/-$ & $-/-$ & $+/+$ & $+/+$ \\
\hline E.coli & $4 \mathrm{~h}$ & $-/-$ & $-/-$ & $-/-$ & $+/+$ & $+/+$ \\
\hline E.coli & $28 \mathrm{~h}$ & $-/-$ & $-/-$ & $-/-$ & $-/-$ & $-/-$ \\
\hline
\end{tabular}

${ }^{a)} \mathrm{n} / \mathrm{a}$, not available

Abb. 1

Anzahl der koloniebildenden Einheiten (CFUs) von L. monocytogenes auf den Holz- und den Glasoberflächen nach sechs unterschiedlichen Inkubationszeiten. Angegeben sind der Mittelwert aus fünf Proben und die Standardabweichung.

Abb. 2

Anzahl der koloniebildenden Einheiten (CFUs) von E. coli auf den Holz- und den Glasoberflächen nach sechs unterschiedlichen Inkubationszeiten. Angegeben sind der Mittelwert aus fünf Proben und die Standardabweichung. 
Ejwwp453_source

Tabelle 1

Bakterielles Wachstum von L. monocytogenes und E. coli auf Holzoberflächen in den zwei Kulturen. + oder - vor dem Schrägstrich gibt an, ob bakterielles

Wachstum nach dem Vortexen auftrat und + oder - nach dem Schrägstrich gibt an, ob nach einer weiteren eintägigen Inkubationszeit bei $37^{\circ} \mathrm{C}$ in der BHILösung bakterielles Wachstum auftrat 
Ejwwp453_source

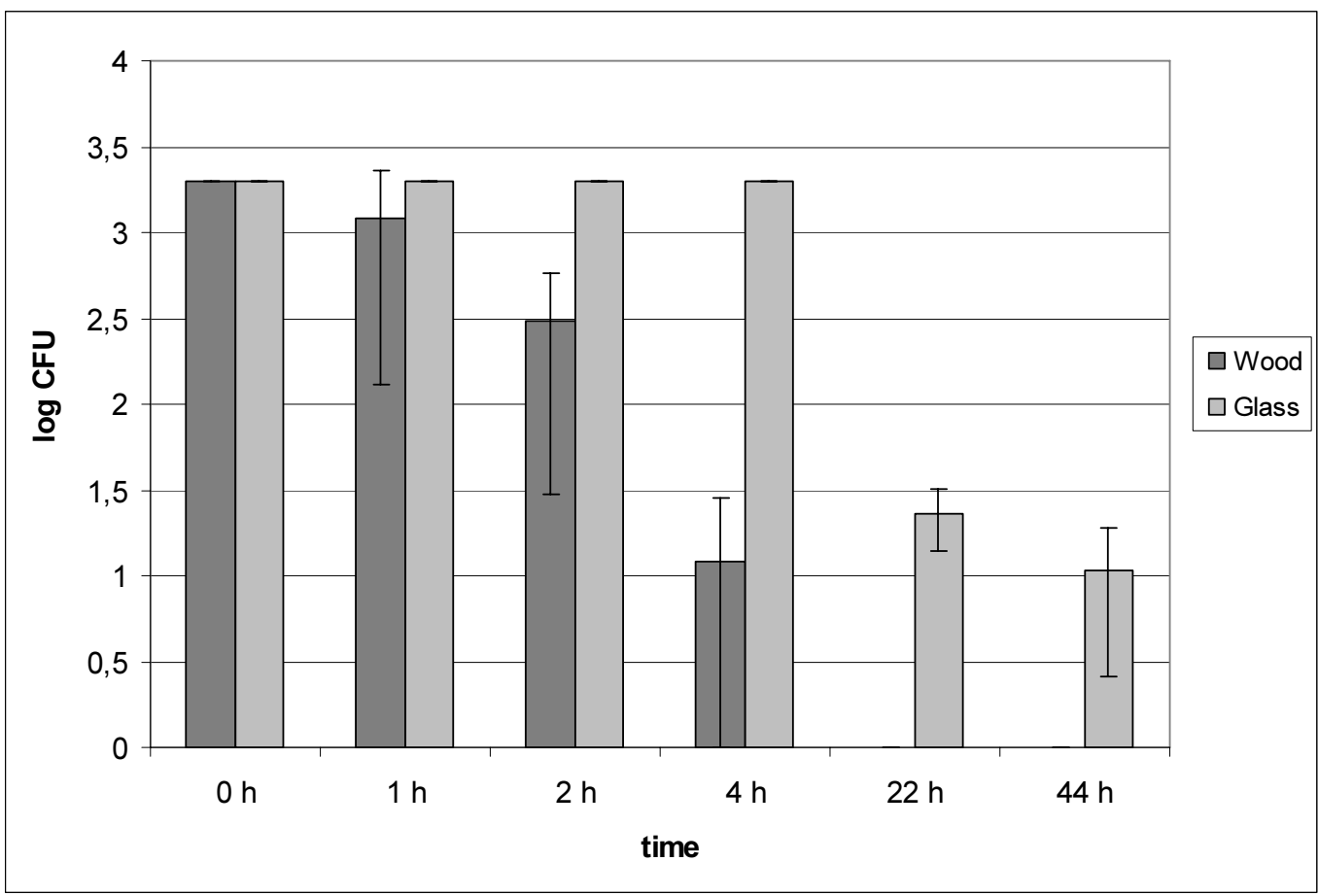

Figure 1.

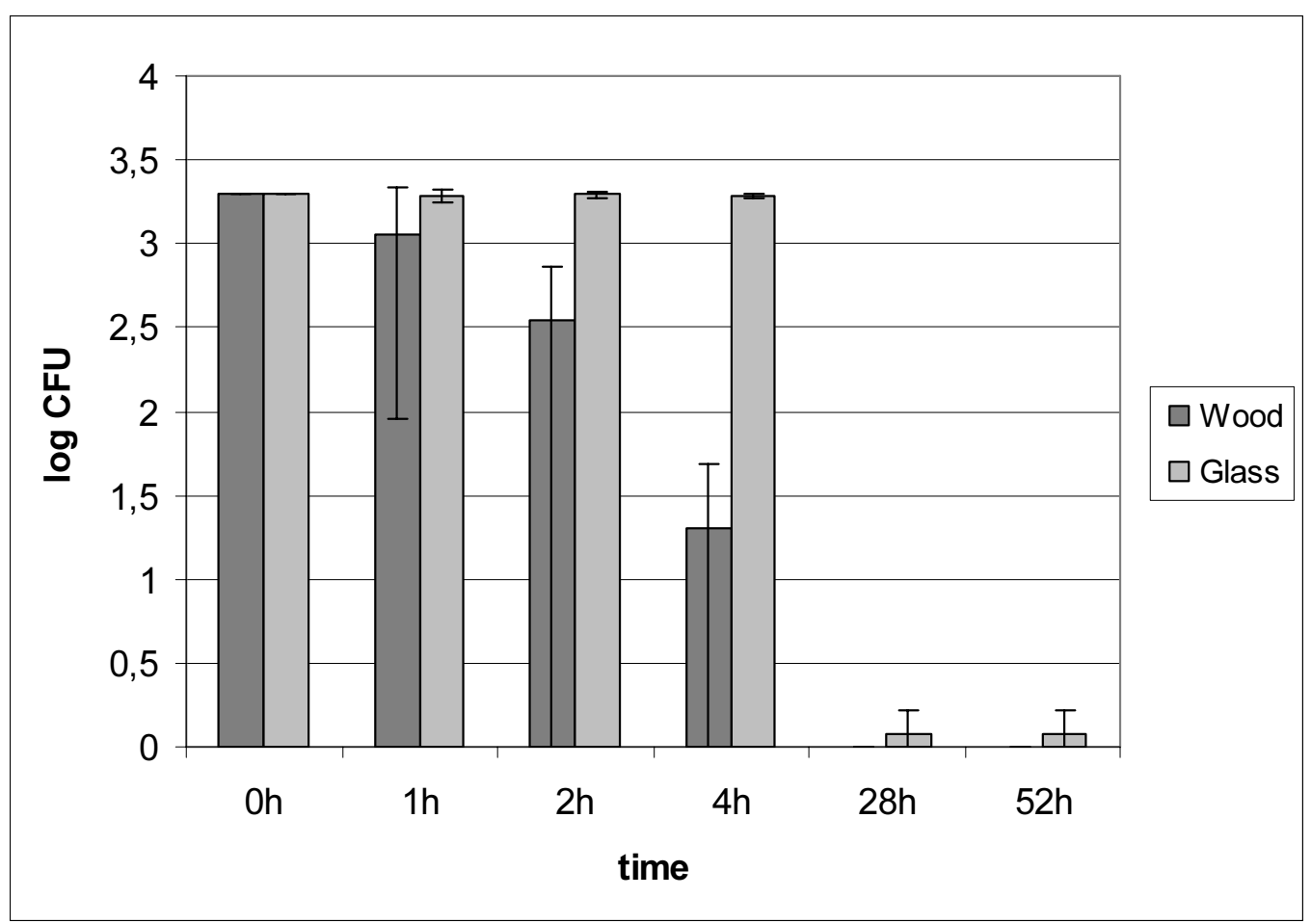

Figure 2. 